\title{
APLIKASI BOOKING KOST BERBASIS ANDROID DI KOTA PALANGKA RAYA
}

\author{
Enny Dwi Oktaviyani ${ }^{\mathrm{a}, 1, *}$, Deddy Ronaldo ${ }^{\mathrm{b}, 2}$, Mustafa Arifin ${ }^{\mathrm{c}, 3}$ \\ ${ }^{a}$ Universitas Palangka Raya, Jl. H. Timang \\ ${ }^{\mathrm{b}}$ Universitas Palangka Raya, Jl. H. Timang \\ ${ }^{\text {c }}$ Universitas Palangka Raya, Jl. H. Timang \\ 1 enny.obrien@gmail.com*; ${ }^{2}$ deddy.ronaldo@gmail.com; ${ }^{3}$ mustafaarifin.ti13@gmail.com \\ * corresponding author
}

ARTICLE INFO

Keywords

Android

Booking Kos

Waterfall

\section{ABSTRACT}

The development of information technology and computers is currently very rapid, especially in the field of communication technology, namely smartphones. While the operating system is currently very well known by the public, namely the Android operating system. The city of Palangka Raya is one of the places of education that is the destination of prospective students from various regions. Then they have to find a place to stay while the study is finished and this process will waste a lot of time. So from that we need a facility or media to facilitate the search process of kos by utilizing smartphone technology and the Android operating system.

The method used to design and build this application is the waterfall method. The design process is using flowcharts, use case diagrams, activity diagrams, class diagrams, database design and user interface design. Supporting applications are Sublime Text, Android Studio, XAMPP, MySQLyog and blackbox testing.

\section{Pendahuluan}

Salah satu masalah yang dihadapi mahasiswa yang akan menjalani studi ataupun menjalani kuliah ditempat yang jauh dari daerah asal mereka adalah tempat tinggal. Untuk itu mahasiswa harus segera mencari tempat tinggal sementara untuk dijadikan domisili mereka sampai studi selesai. Info tentang tempat tinggal atau kos biasa didapat dari mulut ke mulut, selebaran kertas yang ditempel, atau iklan spanduk yang di pajang pada pinggiran jalan. Dan belum lagi untuk mencari kos dengan menggunakan kendaraan dalam ruang lingkungan yang luas, selain itu seorang pencari kos harus menghubungi pemilik kos tersebut untuk proses pemesanan dan lain sebagainya lalu dilanjutkan dengan mencari kos lain untuk melihat kos-kosan yang cocok, sehingga cara ini sangatlah merepotkan dan membuang banyak waktu.

Kota Palangka Raya merupakan salah satu tempat pendidikan yang menjadi tujuan utama calon mahasiswa untuk menuntut ilmu. Selain itu kebutuhan akan tempat tinggal juga sangatlah penting untuk para calon mahasiswa yang berasal dari luar kota. Sehingga pada penelitian ini akan dirancang sebuah sistem yang digunakan untuk menyampaikan informasi tentang kos kepada calon penghuni yang sedang mencari dan dapat melakukan pemesanan terhadap kamar kos lewat aplikasi berbasis Android yang terinstall di smartphone pengguna.

Penelitian ini bertujuan untuk membuat sebuah aplikasi yang menyediakan berbagai informasi tentang ketersediaan kamar kos dan bagaimana cara melakukan pemesanan kos secara online bagi para pencari kos dan bertujuan sebagai media promosi rumah kos miliknya sehingga diharapkan dapat meningkatkan produktifitas pemasaran bagi pemilik kos. Aplikasi dibuat menggunakan bahasa pemrograman PHP, database MySQL, dan android studio untuk pembuatan program Mobile Android $[1][2][3][4]$. 


\section{Kos}

Indekos atau kos adalah sebuah jasa yang menawarkan sebuah kamar atau tempat untuk ditinggali dengan sejumlah pembayaran tertentu untuk setiap periode tertentu (umumnya pembayaran per bulan). Kata ini diserap dari frasa bahasa Belanda "in de kos". Definisi "in de kos" sebenarnya adalah "makan di dalam", tetapi dapat pula berarti "tinggal dan ikut makan" di dalam rumah tempat menumpang tinggal.

\section{Android}

Android adalah sistem operasi yang berbasis Linux untuk telepon seluler seperti telepon pintar dan komputer tablet. Android menyediakan platform terbuka bagi para pengembang untuk menciptakan aplikasi mereka sendiri untuk digunakan oleh bermacam peranti bergerak. Android awalnya dikembangkan oleh Android, Inc., dengan dukungan finansial dari Google, yang kemudian membelinya pada tahun 2005. Sistem operasi ini dirilis secara resmi pada tahun 2007. Kemudian untuk mengembangkan Android, dibentuklah Open Handset Alliance, konsorsium dari 34 perusahaan peranti keras, peranti lunak, dan telekomunikasi, termasuk Google, HTC, Intel, Motorola, Qualcomm, T-Mobile, dan Nvidia. Kelebihan android adalah [7]:

a. User Friendly, yang dimaksudkan disini adalah sistem Android sangat mudah untuk dijalankan. Sama halnya pada sistem operasi Windows yang ada pada komputer. Bagi anda yang belum terlalu terbiasa dengan smartphone, anda hanya membutuhkan waktu sebentar saja untuk bisa mempelajari sistem Android.

b. Anda akan sangat mudah mendapat beragam notifikasi dari smartphone anda. Untuk mendapatkannya, anda bisa mengatur beberapa akun yang anda miliki seperti SMS, Email, Voice Dial, dan lainnya.

c. Keunggulan lainnya terdapat dari segi tampilan sistem Android yang menarik dan tidak kalah baiknya dengan iOS (Apple). Hal ini dikarenakan dari awal, Android memang mengusung konsep dan teknologi iOS hanya saja Android merupakan versi murah dari iOS.

d. Sistem operasi ini memang memiliki konsep open source yang mana pengguna dapat bebas mengembangkan sistem android versi milikinya sendiri. Sehingga akan banyak sekali custom ROM yang bisa anda gunakan.

e. Tersedia beragam pilihan aplikasi menarik, bahkan hingga jutaan aplikasi. Dari mulai aplikasi gratis hingga aplikasi berbayar. Anda dapat mendownloadnya langsung di Google Playstore yang tersedia pada smartphone anda.

\section{Metodologi Penelitian}

Metodologi penelitian yang digunakan dalam merancang dan membangun Aplikasi ini meliputi metode pengumpulan data yaitu dengan menanyakan informasi tentang kos dan data-data yang bersangkutan langsung kepada sumbernya. Menggunakan metode pengembangan perangkat lunak waterfall [1] yang meliputi :

1. Requirements Definition (Definisi Kebutuhan)

2. System and Software Design (Desain Sistem dan Perangkat Lunak)

3. Implementation and Unit Testing (Implementasi dan Pengujian Unit)

4. Integration and System Testing (Pengintregrasian dan Pengujian Sistem)

5. Operation and Maintenance (Pengoperasian dan Pemeliharaan) 


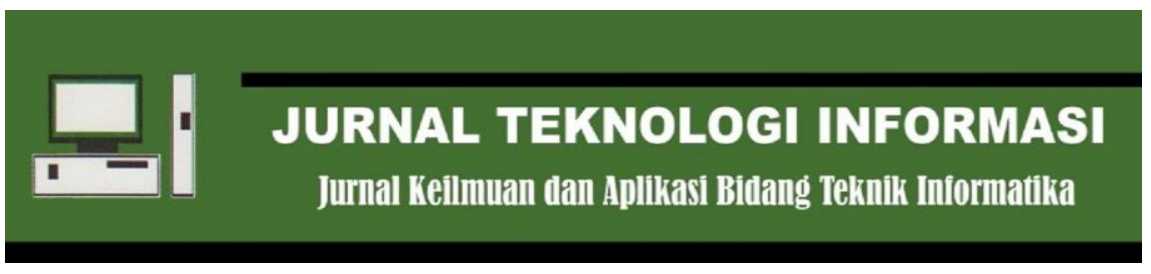

[E-ISSN 2656-0321]

[Vol 13. No. 2]

[Agustus 2019]

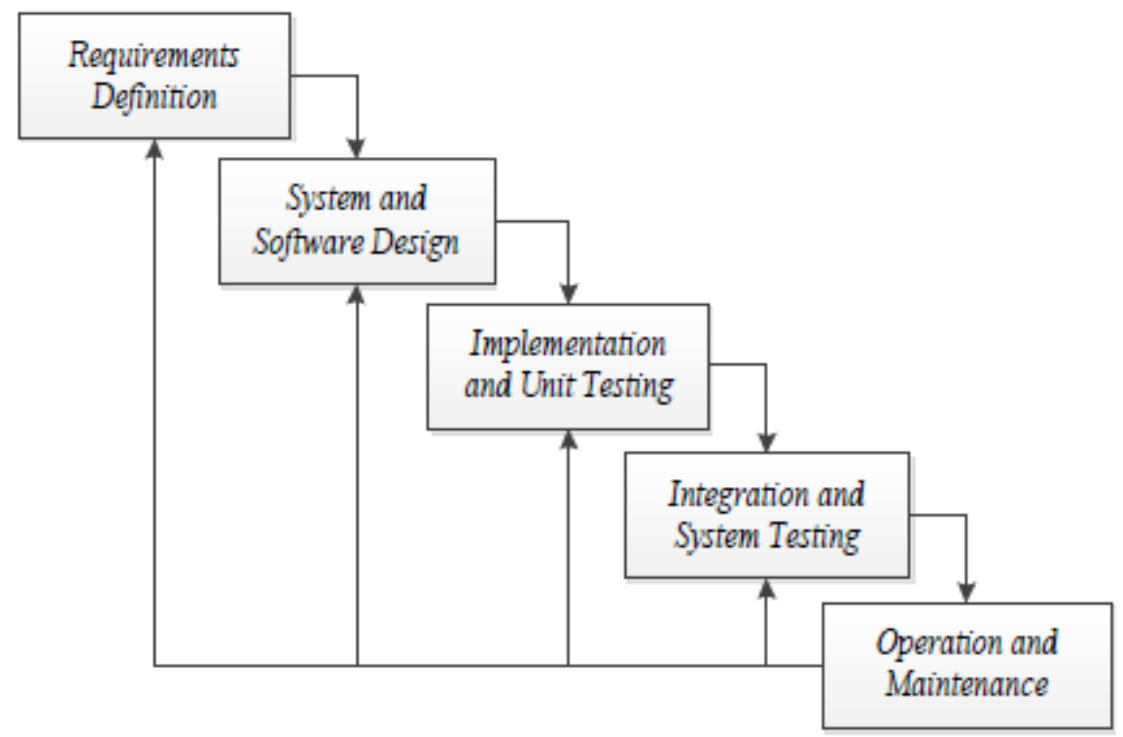

Gambar 1. Metode Waterfall

\section{Hasil dan Pembahasan}

\subsection{Analisis Sistem Lama}

Masalah yang dihadapi dalam hal ini yaitu ketika seseorang ingin mencari tempat tinggal sementara atau sebut saja kos. Cara yang mereka lakukan yaitu dengan mencari informasi kepada teman-teman, kerabat atau kepada orang yang mereka temui atau dengan melihat lembaran kertas atau spanduk yang ditempel, yang berisi tentang informasi kos kosong. Selain itu, mereka juga akan mencari kos dengan cara berkeliling menggunakan kendaraan disekitaran kota dan berharap mendapat informasi seperti spanduk yang terpampang di pinggiran jalan, lalu mereka akan menghubungi nomor telepon yang tercantum pada spanduk tersebut. Dari sisi pemilik kos penyampaian informasi masih dilakukan dengan cara menempel lembaran kertas atau spanduk pada tempat yang kemungkinan akan dilihat oleh orang lain. Sehingga cara ini sangat membuang waktu dan melelahkan karena kertas yang akan ditempel tidak hanya pada satu tempat saja melaikan bisa ditempel pada tempat lain juga, agar kesempatan untuk mendapatkan calon penghuni lebih tinggi. Setelah melakukan analisis sistem lama dan merekomendasikan sistem baru, maka dibuatlah proses bisnis menggunakan flowchart. Flowchart adalah representasi grafis dari langkah - langkah yang harus diikuti dalam menyelesaikan suatu permasalahan yang terdiri atas sekumpulan simbol, dimana masing - masing simbol merepresentasikan kegiatan tertentu. Flowchart diawali dengan penerimaan input dan diakhiri dengan penampilan output. Bagan alir program (program flowchart) merupakan bagian yang menjelaskan secara rinci langkah-langkah dari proses program [5].

\subsection{Rekomendasi Sistem Baru}

1. Pemilik kos tidak lagi melakukan proses pencetakan dan penempelan karena informasi tentang kos kosong akan diupload ke dalam sistem baru berupa banner yang diiklankan. Selain itu informasi tentang kos sudah tercantum pada deskripsi sistem baru termasuk lokasi kos tersebut.

2. Selain itu, sistem ini akan mempermudah pemilik kos saat mengelola data penghuni karena data akan tersimpan dalam basis data sehingga pemilik kos tidak lagi membuat pembukuan untuk menyimpan data penghuni

3. Seorang pencari kos tidak lagi mencari dengan berkeliling kota melainkan hanya dengan membuka aplikasi sistem baru yang akan dibangun dan dirancang nantinya sehingga mereka bisa melihat informasi tentang kos dan mereka dapat langsung memesan kamar kos yang sedang kosong 


\section{JURNAL TEKNOLOGI INFORMASI}

[E-ISSN 2656-0321]

[Vol 13. No. 2]

Jurnal Keeilmuan dan Apilkasi Bidang Teknik Informatika

4. Pengguna dapat mengirim ulasan dan rating tentang kos yang mereka tempati.

\subsection{Pengguna Sistem}

\section{Administrator}

Administrator atau admin adalah seorang yang memiliki hak akses penuh terhadap sistem dan berhak mengelola semua data yang ada dalam database.

\section{Pemilik Kos}

Pemilik Kos adalah seorang pengguna yang memiliki hak akses terbatas yang hanya berhak mengelola data yang berkaitan tentang rumah kos miliknya saja.

\section{Member}

Member adalah seorang pengguna yang telah terdaftar di dalam sistem dan memiliki hak akses sebagai pencari kos.

\subsection{Use case Diagram}

Diagram Use case sistem pada aplikasi ini dibuat berdasarkan masing-masing proses sesuai dengan definisi actor dan use case yang terdapat pada tabel 3.1 dibawah ini :

Tabel 3.1 Tabel Deskripsi Use case

\begin{tabular}{|c|c|c|}
\hline No & Actor & Deskripsi \\
\hline 1 & Admin & $\begin{array}{l}\text { Seorang Administrator dapat mengelola seluruh konten dalam website dan memiliki } \\
\text { hak akses sebagai berikut } \\
\text { 1. Admin melakukan Login. } \\
\text { 2. Dapat mengirim permintaan lupa password jika admin lupa password, input } \\
\text { 3. } \\
\text { 3assword baru } \\
\text { 4. Dapat melihat dan mengelola profil saya (admin) } \\
\text { 5. Dapat melihat dan mengelola data RT } \\
\text { 6. Dapat melihat dan mengelola data RW } \\
\text { 7. Dapat melihat dan mengelola data kecamatan } \\
\text { 8. } \\
\text { 9. Dapat melihat dan mengelola dakun pemilik kos } \\
\text { 10. Dapat melihat dan mengelola akun member; } \\
\text { 11. Dapat melihat dan mengelola data rumah kos; } \\
\text { 12. Dapat melihat dan mengelola data kamar kos; } \\
\text { 13. Dapat melihat dan mengelola data foto; } \\
\text { 14. Dapat melihat dan mengelola data penyewaan; } \\
\text { 15. Dapat melihat dan mengelola data ulasan dan rating; } \\
\text { 16. Dapat melihat dan mengelola data banner iklan; } \\
\text { 17. Melihat dan mengelola data riwayat penyewaan; } \\
\text { 18. } \text { Admin dapat melakukan Logout. }\end{array}$ \\
\hline 2 & Pemilik Kos & $\begin{array}{l}\text { Seorang Pemilik Kos dapat mengelola beberapa konten dalam sistem dan memiliki } \\
\text { hak akses sebagai berikut: } \\
\text { 1. Dapat Login; } \\
\text { 2. Dapat mendaftar; } \\
\text { 3. Dapat mengirim permintaan lupa password; } \\
\text { 4. Melakukan Verifikasi Akun dan Rumah Kos } \\
\text { 5. Dapat melihat dan mengelola profil saya (pemilik kos); } \\
\text { 6. Dapat melihat dan mengelola data rumah kos; } \\
\text { 7. Dapat melihat dan mengelola data kamar kos; } \\
\text { 8. Dapat melihat dan mengelola data peta; } \\
\text { 9. Dapat melihat dan kelola data foto; } \\
\text { 10. Dapat melihat dan mengelola data penyewaan; } \\
\text { 11. Dapat melihat ulasan dan rating; } \\
\text { 12. Melihat dan mengelola data riwayat penyewaan; }\end{array}$ \\
\hline
\end{tabular}




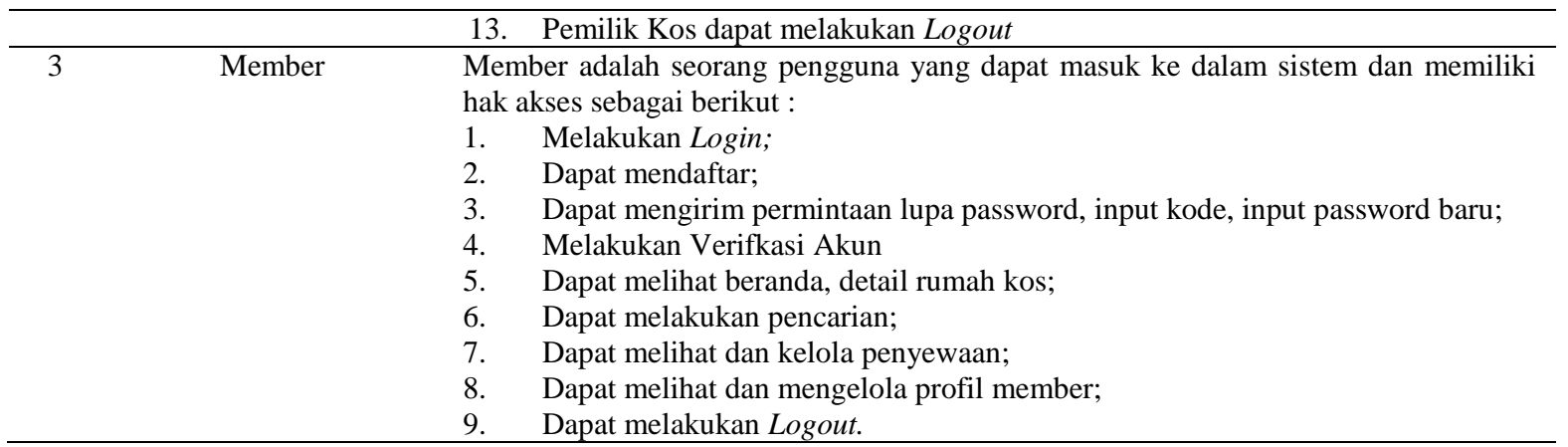

Berdasarkan deskripsi use case tersebut, maka dapat dibuat use case diagram. Use Case diagram menggambarkan sejumlah external actors dan hubungannya ke use case yang diberikan oleh sistem. Use case adalah deskripsi fungsi yang disediakan oleh sistem dalam bentuk teks sebagai dokumentasi dari use case symbol. Use case digambarkan hanya yang dilihat dari luar oleh actor (keadaan lingkungan sistem yang dilihat user) dan bukan bagaimana fungsi yang ada di dalam sistem [6]. Use case diagram untuk admin dapat dilihat pada gambar 2, Use case diagram untuk pemilik kos dapat dilihat pada gambar 3, dan use case diagram untuk member dapat dilihat pada gambar 4 .

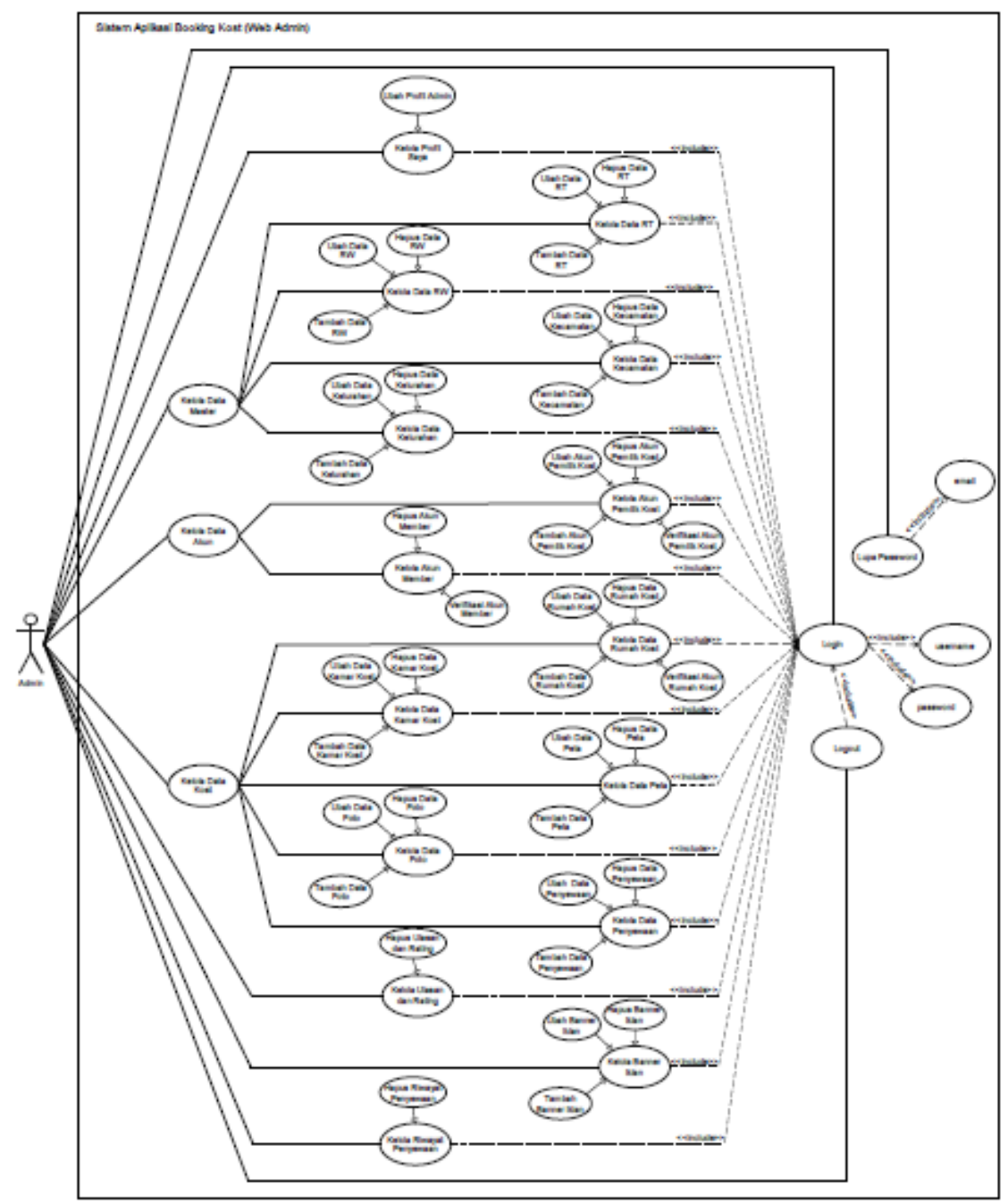

Gambar 2. Use case Diagram Admin 


\section{Jurnal Keilmuan dan Aplikasi Bidang Teknik Informatika}

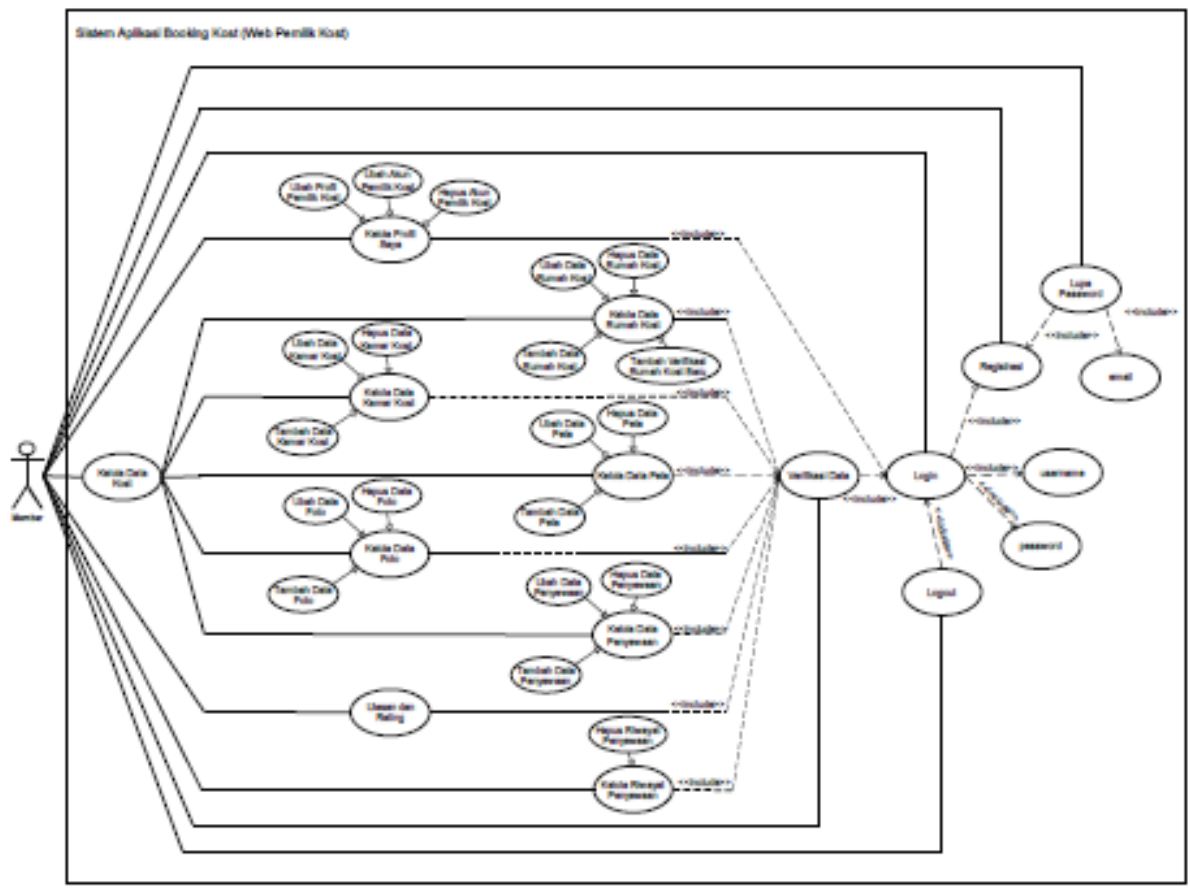

Gambar 3. Use case Diagram Pemilik Kos

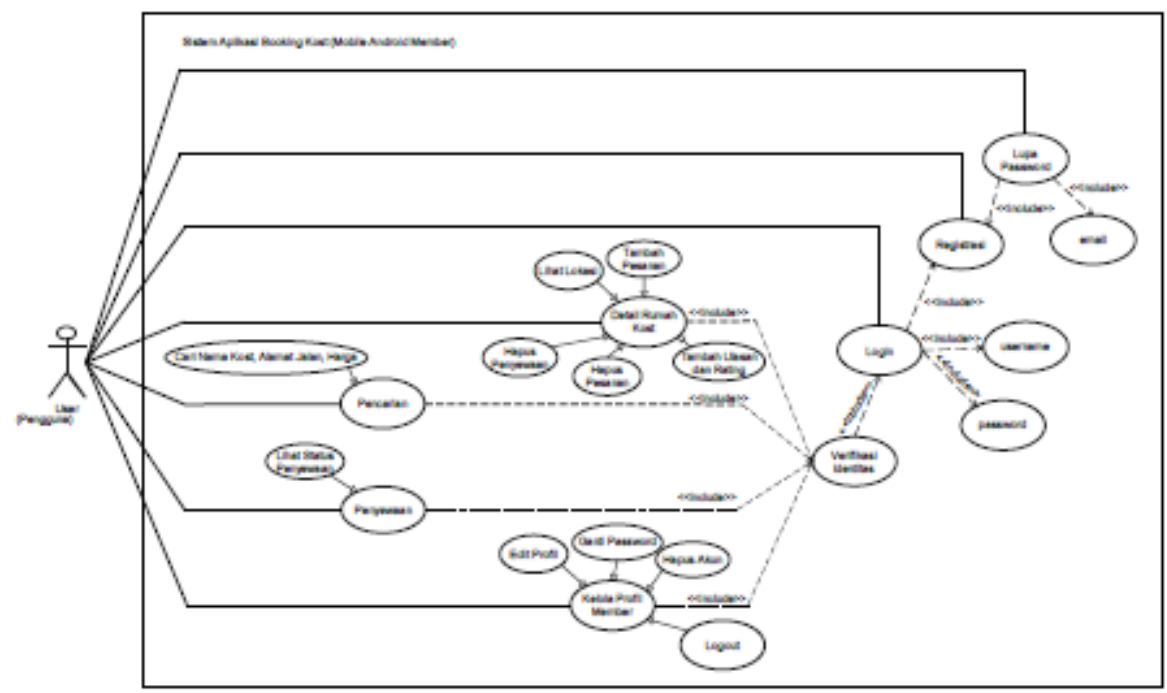

Gambar 4. Use case Diagram Member

\subsection{Class diagram}

Menggambarkan struktur statis class di dalam sistem. Class merepresentasikan sesuatu yang ditangani oleh sistem. Class dapat berhubungan dengan yang lain melalui berbagai cara: associated (terhubung satu sama lain), dependent (satu class tergantung/ menggunakan class yang lain), specialed (satu class merupakan spesialisasi dari class lainnya), atau package (grup bersama sebagai satu unit). Sebuah sistem biasanya mempunyai beberapa class diagram [6]. Class diagram pada penelitian ini dapat dapat dilihat pada gambar 5 
[E-ISSN 2656-0321]

[Vol 13. No. 2]

JURNAL TEKNOLOGI INFORMASI

[Agustus 2019]

\section{Jurnal Keilmuan dan Aplikasi Bidang Teknik Informatika}

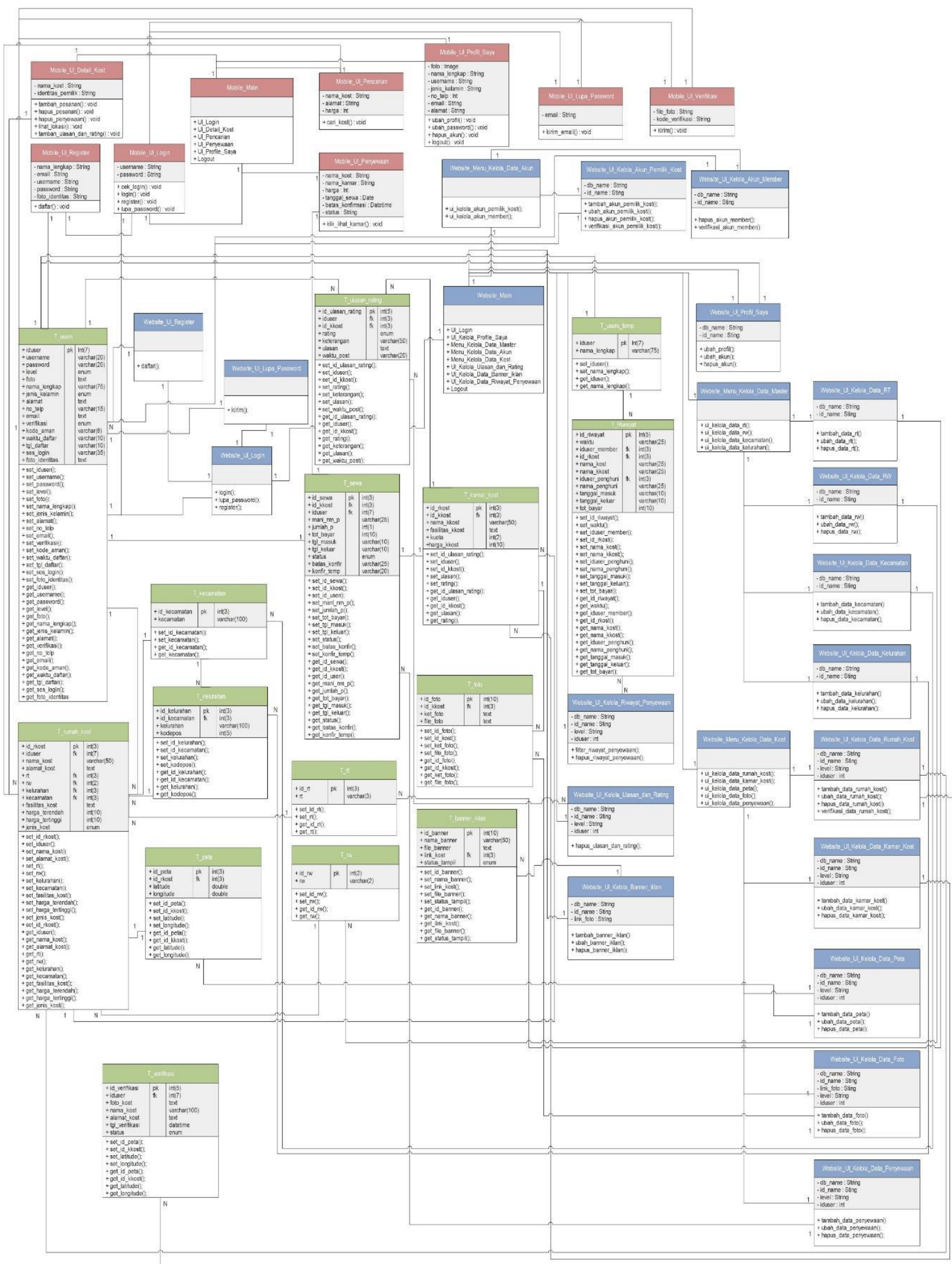

Gambar 5. Class diagram Aplikasi Booking Kos Berbasis Android (Studi Kasus : Kota Palangka Raya

5.6. Antarmuka Pada Website 


\section{JURNAL TEKNOLOGI INFORMASI}

[E-ISSN 2656-0321]

[Vol 13. No. 2]

\section{Jurnal Keillmuan dan Aplikasi Bidang Teknik Informatika}

1. Halaman Beranda Administrator

Pada halaman beranda administrator ini pengguna dapat mengakses keseluruhan data yang ada dalam database yaitu berupa data profil, data akun pemilik kos, data akun member, data rt, data rw, data kecamatan, data kelurahan, data rumah kos, data kamar kos, data peta, data foto, data penyewaan, data banner iklan, data ulasan dan rating, dan data riwayat penyewaan

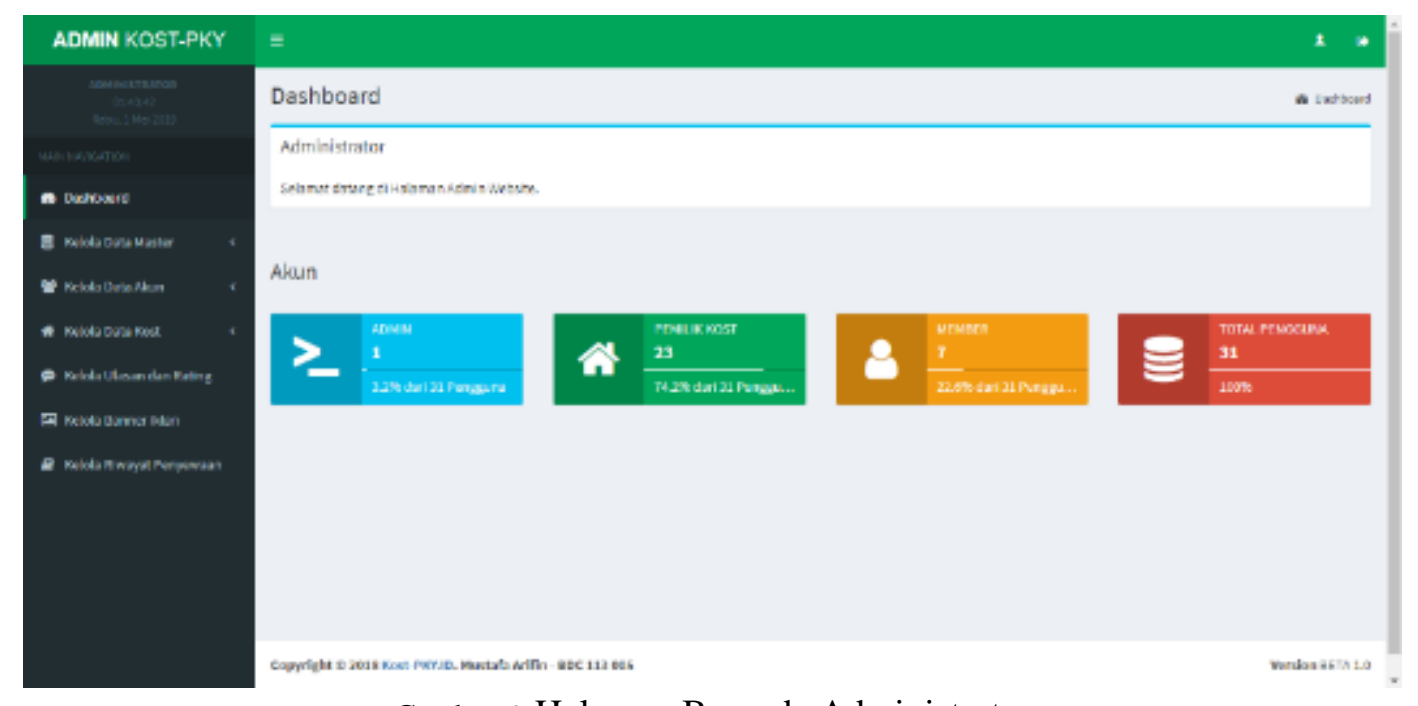

Gambar 6. Halaman Beranda Administrator

\section{Halaman Beranda Pemilik KosMendaftar}

Pada halaman beranda pemilik kos terdapat halaman untuk melakukan verifikasi akun, tujuan yaitu untuk memastikan kebenaran data akun dan rumah kos

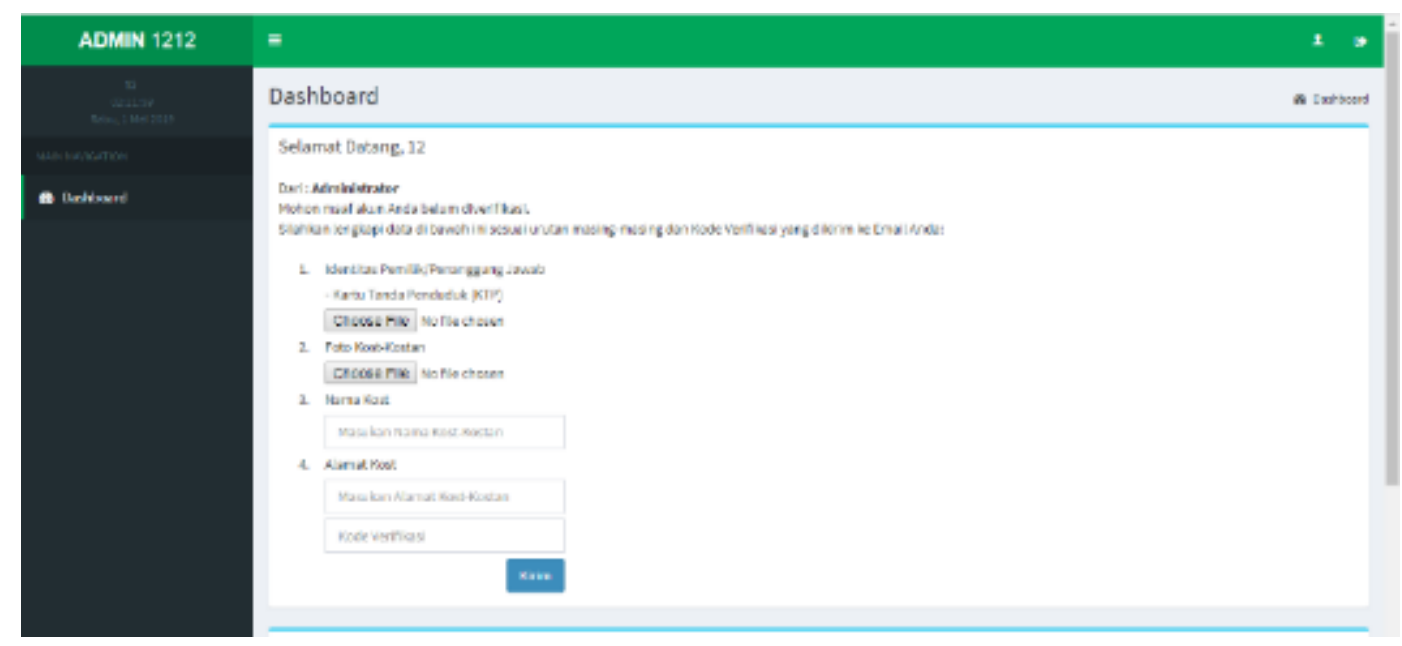




\section{Jurnal Keilmuan dan Aplikasi Bichang Teknik Informatika}

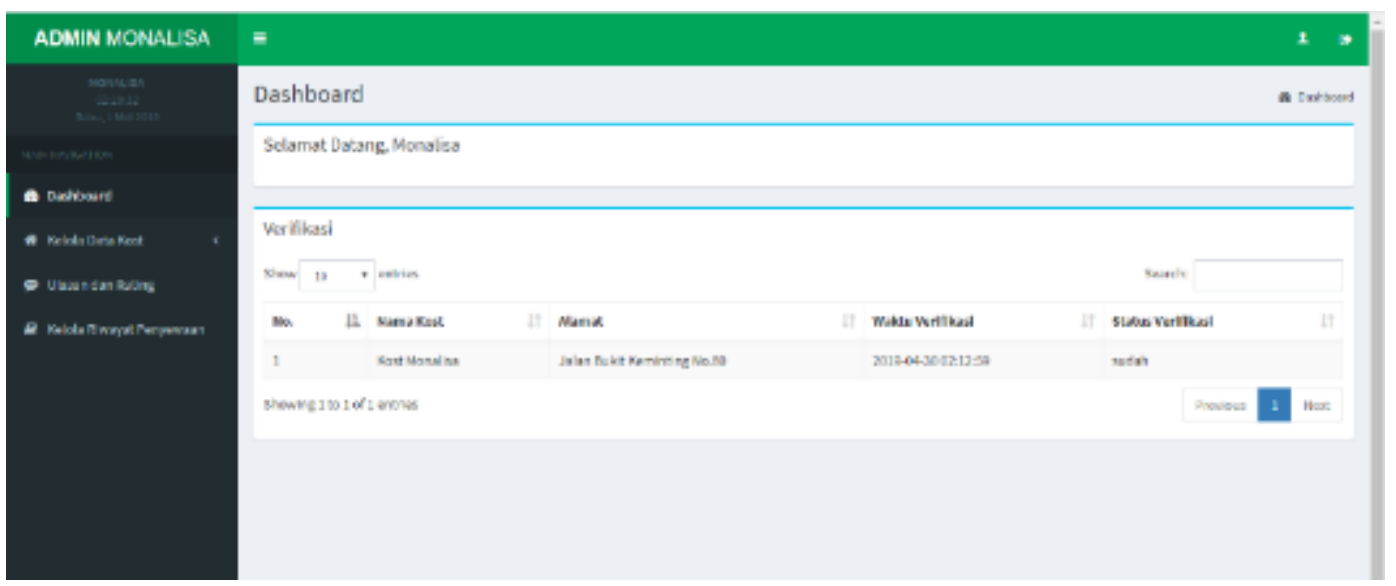

Gambar 7 Halaman Beranda Pemilik Kos

3. Halaman Beranda Aplikasi Mobile

Pada halaman beranda aplikasi mobile ini, member dapat melihat rating kos yang popular, sehingga member dapat memilih kos yang terbaik menurut member. Halaman beranda pada aplikasimobile dapat dilihat pada gambar 8 .
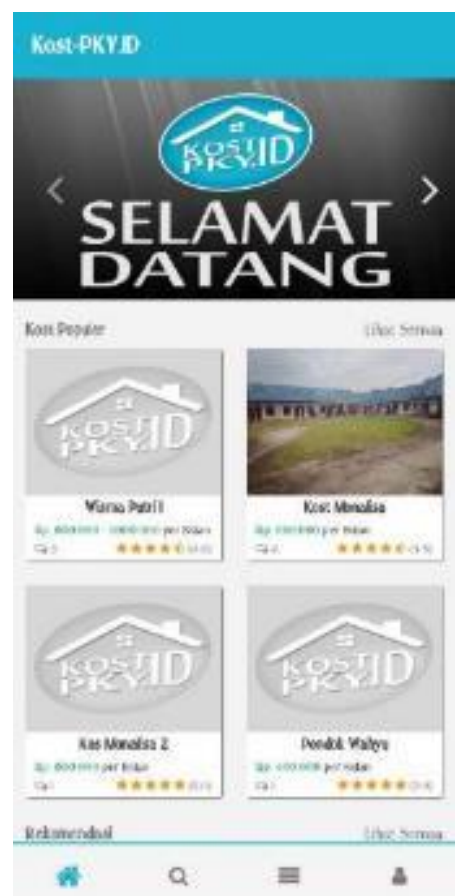

Gambar 8. Halaman Beranda Aplikasi Mobile

\section{Halamat Detail Kos}

Member juga dapat melihat detail kos untuk melihat profil kos berdasarkan harga, jumlah kamar tersedia, jenis kos, alamat kos yang sesuai dengan kebutuhan member. Gambar 9 menunjukkan halaman detail kos. Selain itu, member juga dapat melakukan pencarian pada halaman pencarian berdasarkan nama kos, alamat kos, urutan harga kos dari yang kecil sampai terbesar. Member juga dapat melakukan penyewaan kos secara online. 


\section{JURNAL TEKNOLOGI INFORMASI}

[E-ISSN 2656-0321]

[Vol 13. No. 2]

\section{Jurnal Keeilmuan dan Apilkasi Bitang Teknik Informatika}

[Agustus 2019]

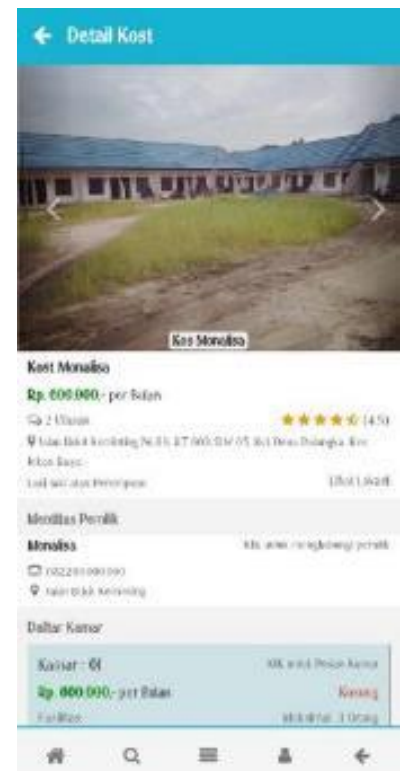

6. Kesimpulan

Gambar 9. Halaman Detail Kos Aplikasi Mobile

a. Website Administrator Aplikasi Booking Kos ini dibuat dengan menggunakan Bahasa pemrograman HTML, PHP, CSS dan Javascript. Selain itu juga menggunakan Framework CodeIgniter untuk struktur sistem agar mempermudah pekerjaan, susunan lebih rapi, keamanan dan lain-lain dan juga Bootstrap AdminLTE untuk template halaman website. Website ini sudah terintegrasi dengan basis data MySQL yang terhubung dengan internet sehingga pengguna dapat mengakses website darimana saja dan kapan saja selama perangkat terkoneksi internet.

b. Aplikasi Booking Kos versi Android pengembangannya menggunakan Aplikasi Android Studio yang dibuat dalam bahasa pemrograman java. Dalam versi Android ini juga sudah terintegrasi dengan basis data MySQL sehingga antara Website dan Aplikasi versi Android sudah tersinkronisasi.

Untuk penelitian lebih lanjut aplikasi ini lebih dikembangkan lagi, dalam arti area yang digunakan tidak hanya kota Palangka Raya saja melainkan wilayah-wilayah lain sehingga pengguna akan lebih bertambah dan juga akan pempermudah pencarian kos di wilayah-wilayah tersebut.

\section{Daftar Pustaka}

[1] Agung dan Hikmah Baitul dkk, "Cara Cepat Membangun Website dari Nol", ANDI. Yogyakarta, 2015.

[2] Darmawan, Deni dan P.H. Deden, “Desain dan Pemrograman Website”, Bandung : Remaja Rosdakarya, 2013

[3] Kadir Abdul, “Mudah Mempelajari Database MySQL”, Yogyakarta : ANDI, 2010

[4] 2009. Membuat Aplikasi Web dengan PHP+Database MySQL. Yogyakarta : ANDI.

[5] Nilawati Ramadona. 2005. "Definisi dan Simbol Flowchart", (From : www.rama.staff.gunadarma.ac.id). Diakses 27 September 2018. 
[6] Pratama, Aditya Rahmatullah. 2016. Mengenal Diagram UML (Unified Modeling Language). (From: https://www.codepolitan.com/mengenal-diagram-uml-unified-modeling-language). Diakses Diakses 27 September 2018.

[7] Shabrina, Reza. 2017. Pengertian Android Beserta Kelebihan dan Kekurangannya. (From: https://www.nesabamedia.com/pengertian-android-beserta-kelebihan-dan-kekurangannya/). Diakses 27 September 2018.

[8] Wikipedia. Indekos. (From: https://id.wikipedia.org/wiki/Indekos). Diakses 27 September 2018. 